\title{
Catch per unit effort, condition factor and length-weight relationship of albacore tuna (Thunnus alalunga), yellowfin tuna (Thunnus albacares) and bigeye tuna (Thunnus obesus) in the longline tuna fishery in the eastern Pacific Ocean
}

\author{
NYATCHOUBA NSANGUE BRUNO THIERRY, ZHOU CHENG, NJOMOUE PANDONG \\ ACHILLE*, KINDONG RICHARD AND LIUXIONG XU \\ College of Marine Sciences, Shanghai Ocean University, Shanghai - 201306, P. R. China \\ ${ }^{*}$ Laboratory E3M, National High Polytechnic School of Douala, University of Douala, Douak - 2701, Cameroon \\ e-mail: c-zhou@shou.edu.cn
}

\begin{abstract}
Highly migratory tuna species play an important economic role and ecosystem function worldwide. They are mainly caught in tropical and subtropical areas of the Pacific, Atlantic and Indian oceans. Data collected by the Chinese longline fishery in the high seas of the Eastern Pacific Ocean from 2014 to 2015 were analysed to estimate the catch per unit effort (CPUE), length and weight frequency, length-weight relationship, relative condition factor and Fulton's condition factor for albacore tuna (Thunnus alalunga), yellowfin tuna (Thunnus albacares) and bigeye tuna (Thunnus obesus). The results showed that this fishing technique was highly selective for these three species. Albacore tuna represented the major portion of the catches at $76.17 \%$. Yellowfin and bigeye tuna represented 8.24 and $11.68 \%$ of the total of specimens, respectively. The remaining $3.9 \%$ were bycatch such as Katsuwonus pelamis, Acanthocybium solandri, Ruvettus pretiosus, Xiphias gladius, Lampris guttatus, Carcharodon carcharias and Scomberomorus guttatus. The average fork length for albacore tuna was 90-100 cm; yellowfin tuna, $100-130 \mathrm{~cm}$ and bigeye tuna, $125-165 \mathrm{~cm}$. The average weight for albacore tuna was $15-20 \mathrm{~kg}$; yellowfin tuna, 20-50 kg and bigeye tuna, 35-55 kg. The CPUE (based on fish per one thousand hooks) for albacore, yellowfin tuna and bigeye tuna ranged from 1.6 to $9.82,1.07$ to 2.66 and 1.06 to 3.45 , respectively. The parameters of the length-weight relationship showed a negative allometric growth regression of 2.7135 for albacore tuna, 2.3275 for yellowfin tuna and 2.4047 for bigeye tuna. Nevertheless, the albacore and yellowfin tuna females were characterised by positive allometry (b>3). The analyses also showed that the relative condition factors $\left(K_{r e l}\right)$ of the three fish species were greater than one, implying that they were in good physiological condition, good water quality and healthy organisms.
\end{abstract}

Keywords: China, Fishing effort, Fish per hook, Tuna

\section{Introduction}

Tuna fishes belonging to the Scombridae family comprises more than a dozen species (Yuta, 2018). The most commercially important species in the eastern Pacific Ocean are the albacore tuna (Thunnus alalunga), yellowfin tuna (Thunnus albacares) and bigeye tuna (Thunnus obesus) (Zhu et al., 2008). The main albacore tuna fisheries are in temperate and tropical waters. Asian longliners overexploit this species and the catch volume is estimated at 68,000 t. However, the biomass of the stock is not affected by the industry (Goni et al., 2009; Cosgrove et al., 2014, 2015; Froese and Pauly, 2017). With respect to yellowfin tuna, the size of fish caught varied from 40 to $170 \mathrm{~cm}$ TL (1.2 and $100 \mathrm{~kg}$ ) (Collete et al., 2011). The spawning biomass has increased in recent years and the level of fishing mortality in the Eastern Pacific Ocean is slightly below the maximum sustainable yield (MSY) of approximately 13\% (586 400 t) (Froese and Pauly, 2017). Bigeye tuna can grow up to $250 \mathrm{~cm}$ (98 inches) or 8 feet in length. The maximum weight of individuals may exceed $180 \mathrm{~kg}$, the all-tackle angling record is $178 \mathrm{~kg}$ (Grewe and Hampton, 1998). The stock exploited in 2015 was 78,000 t. The species is fully exploited with spawning stock biomass and fishing mortality at MSY (Froese and Pauly, 2017).

The albacore, yellowfin and bigeye tuna are also the principal species of tunas in the trade (Majkowski, 2007). However, the longline tuna fishery in the eastern Pacific has limited regulations which may impact the tuna population and bycatch which needs to be resolved by research on the fishery's sustainability (ICCAT, 2017). Our analysis aims to understand and characterise the biological distribution, tuna species catches and distribution of longline fishers in the eastern Pacific. Our results would lay the foundations 
for developing appropriate management strategies to minimise bycatch and maximise economic performance.

The length-weight relationship (LWR) and Fulton's condition factor $(\mathrm{K})$ are the two major parameters used in fishery research and are closely related (Froese, 2006). These parameters are essential and focus on various important biological aspects, such as the general well-being of fish, appearance of first maturity and onset of spawning, which can be assessed using the condition factors derived from LWR with K (Le Cren, 1951; Pepin, 1995; Shaofei et al., 2015). Our investigation also includes the conversion of growth-in-length equations to growth-in-weight (for use in stock assessment models), estimating the biomass from length data, calculating the total weight of fish caught using length-frequency data, determining the relative condition factor of small fish compared to large fish and comparing the regional life histories of certain fish species (Pitcher and Hart, 1982; Petrakis and Stergiou, 1995; Goncalves et al., 1997; Binohlan et al.,1998; Zhenhua and Gang, 2016). Although LWR and $\mathrm{K}$ reflect the growing conditions of some fish, previous research has not combined these analyses. As a result, consistent trends reflecting the characteristics of albacore, yellowfin and bigeye tuna populations in the eastern Pacific Ocean require further study.

The present study aimed to analyse the developing tuna longline fishery targeting albacore, yellowfin and bigeye tuna in the eastern Pacific Ocean using data collected by Chinese longlines. The species selectivity, catch per unit effort (CPUE), length and weight frequency, LWR and Fulton's condition factor $(\mathrm{K})$ were investigated. This information will assist in managing the rapidly developing tuna longline fishery in the eastern Pacific Ocean.

\section{Materials and methods}

\section{Survey information}

This study was conducted within the east Pacific high seas east of Tahiti Island, French Polynesia $\left(14^{\circ} \mathrm{S}\right.$; $115^{\circ} \mathrm{W}$ and $23^{\circ} \mathrm{S} ; 124^{\circ} \mathrm{W}$ ) (Fig. 1). The longline survey was conducted during the albacore, yellowfin and bigeye tuna season between January 2014 and December 2015. The survey was completed onboard the commercial tuna longliner "Xin shi ji 71" which is $56.5 \mathrm{~m}$ long, $8.5 \mathrm{~m}$ wide and $3.65 \mathrm{~m}$ deep, with a gross tonnage of 634 and main engine power of $735 \mathrm{~kW}$. The fishing location is provided in Fig. 1. Catch and effort data was collected during the fishing season by surveying the daily operation results. A total of 873 specimens were measured. The variables observed during the study were: total fork length (Lt) (to the nearest centimetre), total weight (Wt) (to the nearest kilogram), the total number of fish caught per day and sex of the fish.

\section{Fishing effort and catch per unit effort (CPUE)}

The fishing equipment used in the commercial tuna longliner "Xin shi ji 71" was constructed with nylon monofilament with a diameter of $5.4 \mathrm{~mm}$ with polyester branch lines of $4 \mathrm{~mm}$ diameter attached through swivels. The length of the main rope between the two lines was $33 \mathrm{~m}$, containing 26 branching lines in each branch. During the survey, there was a total of 58 fishing operations (days), representing a fishing effort slightly above 3770 hooks per day. In this study, the time series of fishing effort and species CPUE were used to identify patterns in daily and seasonal variability. The fishing effort (f) and CPUE can be calculated with the following equations, modified from De Metrio and Megalofonou (1988):

$$
\begin{aligned}
& F=\left(\frac{N_{h}}{1000} x f_{d}\right) \\
& \text { CPUE }_{i}=\frac{C_{i}}{f}
\end{aligned}
$$

where $\mathrm{N}_{\mathrm{h}}$ is the number of hooks on the longline per day, $f_{d}$ is the number of fishing days per fishing operation and $\mathrm{C}_{\mathrm{i}}$ is the number of fish caught.

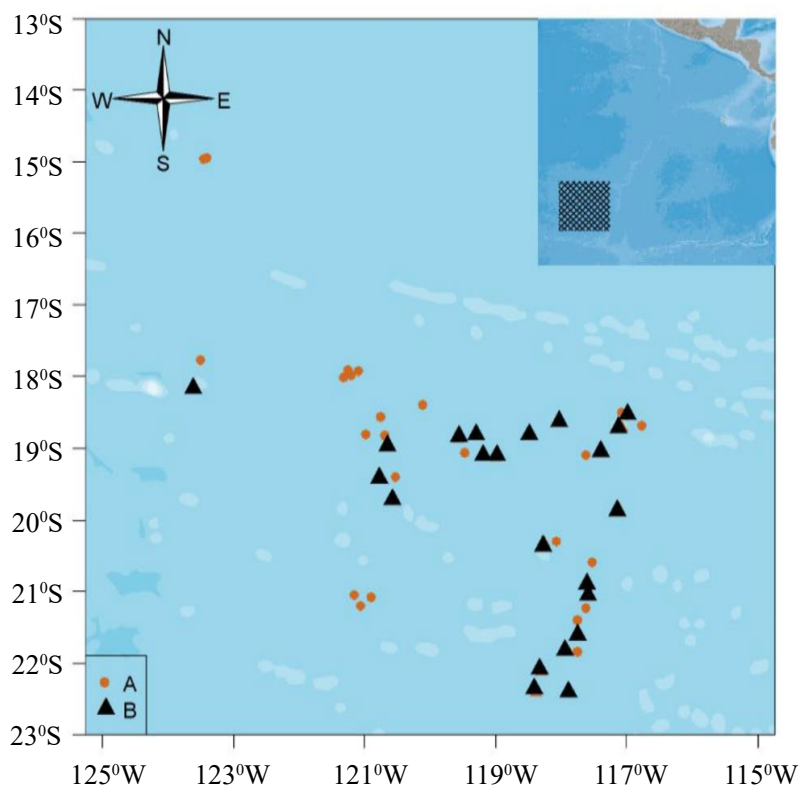

Fig. 1. Distribution of deployment locations in the survey of the tuna longline fishery (A: filled circle indicate counterretrieval-operations and $\mathrm{B}$ : filled triangle indicate forward retrieval operations; the plot in the upper right corner represents the distance from the shoreline of the survey area (shaded in grey) 


\section{Fork length and weight frequency}

The fork length frequency was calculated using a $10 \mathrm{~cm}$ fork length interval between: 80 and $130 \mathrm{~cm}$ for albacore tuna, 85 and $150 \mathrm{~cm}$ for yellowfin tuna and 75 and $180 \mathrm{~cm}$ for bigeye tuna (creating a total of 5, 8 and 10 interval classes in the frequency distributions of albacore, yellowfin and bigeye tuna, respectively). The left boundary was closed in each interval. For example, for the interval of $80-90 \mathrm{~cm}$, the fork length was from $80 \mathrm{~cm}$ $(>80 \mathrm{~cm})$ to $90 \mathrm{~cm}(90 \mathrm{~cm})$.

Weight frequency was calculated using a $5 \mathrm{~kg}$ weight interval that was between 10 and $35 \mathrm{~kg}$ for albacore tuna. The weight interval for yellowfin and bigeye tuna was calculated with a $10 \mathrm{~kg}$ weight interval from 10 to $80 \mathrm{~kg}$ and then a $5 \mathrm{~kg}$ interval for the size of 80 to $110 \mathrm{~kg}$. A total of 5, 6 and 10 intervals for weight frequency distributions were determined for albacore, yellowfin and bigeye tuna, respectively.

\section{Length-weight relationship}

The LWRs were estimated using Eq. 3 (Froese, 2006):

$$
\mathrm{W}_{\mathrm{t}}=\mathrm{aLb}_{\mathrm{t}}
$$

where $\mathrm{W}_{\mathrm{t}}$ is the whole-body weight $(\mathrm{kg}), \mathrm{L}_{\mathrm{t}}$ is the total fork length (cm), $a$ is the power function coefficient (the regression intercept) and $b$ is the allometric coefficient (the regression slope).

The value of $b$ varies from 2 to 4 but is generally close to 3 (N'da et al., $2006 \mathrm{a}$ and b). The value of $\mathrm{b}$ determines the type of growth: $b=3$ shows the growth is isometric and so the specific density of the fish does not change: $b<$ shows the growth is negative allometric and therefore, the fish length increases faster than it grows; $b>3$ shows positive allometry and therefore, the fish grows faster than the increase in its length (Anderson and Neumann, 1996).

Since the LWR (3) is nonlinear, the coefficients $a$ and $b$ cannot be obtained directly and therefore, require further transformation into a linear equation by using natural logarithms on both sides:

$$
\ln \mathrm{W}_{\mathrm{t}}=\ln a+b \ln \mathrm{L}_{\mathrm{t}}
$$

Fulton's condition factor and relative condition factor

For each individual, the relative condition factor $\left(K_{r e l}\right)$ and Fulton's condition factor $(K)$ were calculated using the following equations (Le Cren, 1951; Megalofonou, 1990; Froese, 2006; Macías et al., 2012):

$$
\mathrm{K}_{\mathrm{rel}}=\frac{\mathrm{W}_{\mathrm{t}}}{\mathrm{aL}_{\mathrm{t}}^{\mathrm{b}}}
$$

$$
\mathrm{K}=\frac{\mathrm{W}_{\mathrm{t}}}{\mathrm{L}_{\mathrm{t}}^{3}} \times 100
$$

\section{Results and discussion}

\section{Species composition}

The species composition was estimated as the percentage of occurrence of each species. Albacore represented the highest percentage of all species caught (76.17\%); yellowfin $8.25 \%$ and bigeye tuna $11.68 \%$ of the total catch. Skipjack tuna (Katsuwonus pelamis), wahoo (Acanthocybium solandri) and oilfish (Ruvettus pretiosus) represented $2.75 \%$ of the total catch. All other bycatch species (Xiphias gladius, Lampris guttatus, Carcharodon carcharias and Scomberomorus guttatus) contributed $1.15 \%$ of the total catch (Table 1). These results indicate that the tuna longline used in the eastern Pacific to catch albacore, yellowfin tuna and bigeye tuna was highly selective for these species (Zhu et al., 2008). Mohamed and Eldin (2012) and this study attribute the presence of bycatch species in tuna longlines to the season, gear design and fishing operation.

\section{Fishing effort, daily catch and CPUE}

Fig. 2 shows the daily catch and catch per unit effort (CPUE) of albacore, yellowfin tuna and bigeye tuna based on 58 fishing days during the fishing season. The average fishing effort was approximately 3.77 effort units per day ( 3770 hooks per day). The daily catch of albacore ranged from 6 to 37 fish per day with an average of $13 \pm 4$ fish per day and between 105 and $647.5 \mathrm{~kg}$ per day (Fig. 2a). The daily catch of yellowfin tuna ranged from 4 to 10 fish per day with an average of $5 \pm 2$ fish per day and from 140 to $350 \mathrm{~kg}$ per day with an average of $175 \pm 70 \mathrm{~kg}$ per day (Fig. 2b). The catch of bigeye tuna ranged from 4 to 13 fish per day and between 180 and 585 $\mathrm{kg}$ per day (Fig. 2c). Although albacore catches occurred throughout the 58 fishing days, the CPUE varied from 1.6 to 9.82 and showed significant daily differences. It displayed a unimodal temporal distribution that peaked on 26 November 2015. This result relates to the transition period (between autumn and winter fishing effort) when the distribution of effort was scattered. The lowest CPUE was recorded on 28 October and 26 December, 2015 (Fig. 2a). Furthermore, previous studies by Vayghan et al. (2020) in the southern Atlantic Ocean, Rochman et al. (2017) in the eastern Indian Ocean and Hoyle et al. (2012) in the south Pacific Ocean, suggest that the CPUE of albacore tuna in the present study are comparable to the catches in other oceans. The CPUE for albacore tuna in the Southern Atlantic Ocean during the period of 2009 to 2015 was 7.44 to 41.53 fish per 1000 hooks (Vayghan et al., 2020). In the eastern Indian Ocean during the 
Table 1. Species composition of the high seas pelagic longline tuna fishery in the eastern Pacific Ocean

\begin{tabular}{llll}
\hline Species & Common name & Number of fish caught & \% of total catch \\
\hline Thunnus alalunga & Albacore tuna & 665 & 76.17 \\
Thunnus obesus & Bigeye tuna & 102 & 11.68 \\
Thunnus albacares & Yellowfin tuna & 72 & 8.25 \\
Katsuwonus pelamis & Skipjack tuna & 7 & 0.80 \\
Lampris guttatus & Opah & 2 & 0.23 \\
Acanthocybium solandri & Wahoo & 12 & 1.37 \\
Carcharodon carcharias & Shark & 3 & 0.34 \\
Scomberomorus guttatus & Seerfish & 2 & 0.23 \\
Xiphias gladius & Swordfish & 3 & 0.34 \\
Ruvettus pretiosus & Oilfish & 5 & 0.57 \\
\hline
\end{tabular}

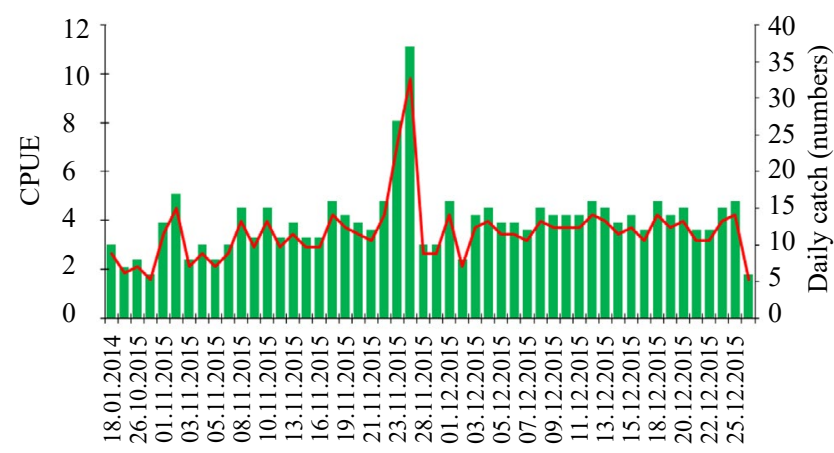

Day

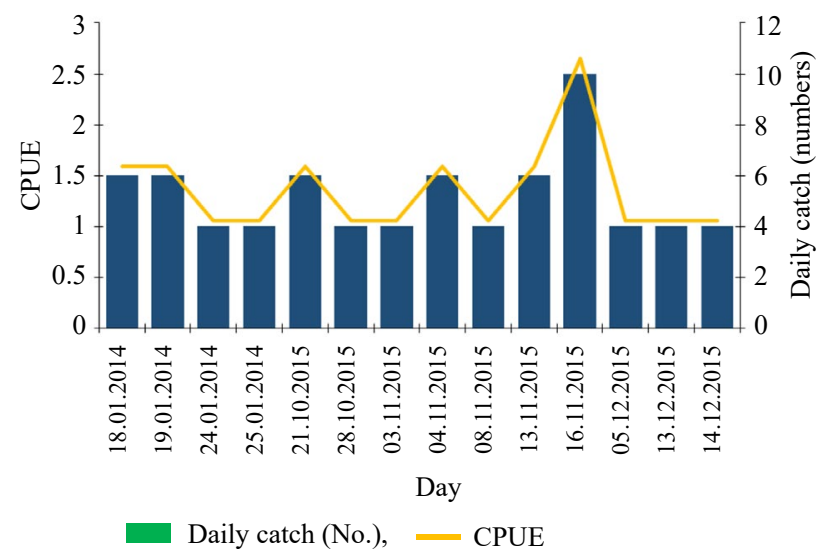

(b)

(a)

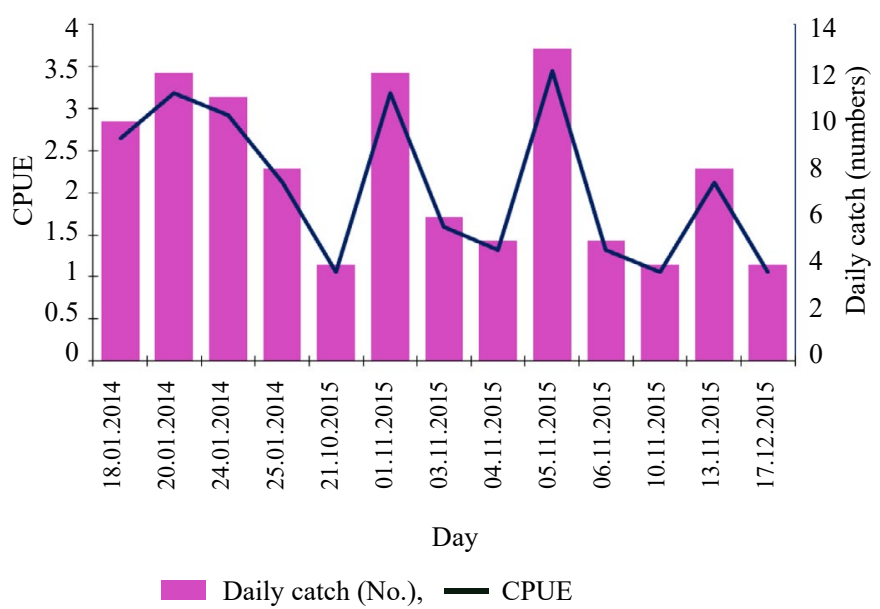

(c)

Fig. 2. Catch per unit effort (CPUE) and daily fish catch in numbers a: Albacore tuna; b: Yellowfin tuna and c: Bigeye tuna

period of 2006 to 2015, the CPUE was from 0.117 to 0.519 fish per 100 hooks (Rochman et al., 2017). In the south Pacific Ocean during the period of 1960 to 2011, the CPUE was from 0.15 to 4 fish per 100 hooks (Hoyle et al., 2012). For yellowfin tuna catches, the CPUE varied from 1.07 to 2.66. The unimodal temporal distribution was evaluated on 16 November 2015 and was found to be related to the transition between autumn and winter fishing efforts. The lowest CPUE was observed between 24 and 25 January 2014; 28 October to 03 November 2015 and 05 to 14 December 2015 (Fig. 2b). The CPUE of yellowfin tuna caught in the Indian Ocean during 19772017 and in the western and central Pacific Ocean during 1960-2014 as reported by Lee et al. (2018) and Davies 
et al. (2014) were similar to those obtained in the present study. Unlike the previous two species, bigeye tuna showed clear seasonality in its catch with three principal peaks: the first during winter season on 20 January 2014 (with a CPUE of 3.18 per unit effort), the second in autumn on 01 November 2015 (with a CPUE of 3.18 per unit effort) and the third one on 05 November 2015 (with a CPUE of 3.45 per unit effort), these peaks related to the beginning of the transition between the autumn and winter fishing effort. The lowest CPUE was recorded on 21 October (autumn fishing effort), 10 November (transition period between autumn and winter fishing effort) and 17 December (winter fishing effort) 2015 (Fig. 2c). Similar to the other two species, the CPUE results of bigeye tuna were also comparable to those reported for the western and central Pacific Ocean during the period 1960-2014 (Davies et al., 2011; Harley et al., 2014). Caution should be taken as the CPUE obtained for albacore, yellowfin and bigeye tuna in this study may not reflect the actual abundance of these species in the fishing area. This is due to the temporal trends in CPUE being strongly influenced by various factors associated with fishing practices and environmental conditions (Sadiyah et al., 2012; Abad-Uribarren et al., 2018; Vayghan et al., 2020). The results obtained in this study are also consistent with the conclusions of Song et al. $(2013 ; 2014)$ with a similar fishing period and fishing season. For example, both studies focused on the target population in a natural period with overlaps in the range of hook distribution due to the vertical movement of the day, night and weather conditions, resulting in variations in CPUE.

\section{Fork length and weight frequency}

The fork length frequency distribution of albacore, yellowfin and bigeye tuna fork lengths is depicted in Fig. 3. The size of albacore tuna ranged from 80 to $130 \mathrm{~cm}$ and the fork length of 90 to $100 \mathrm{~cm}$ were the dominant class of the albacore tuna catches (Fig. 3a). This fork length range represents approximately 69 and $50.8 \%$ of the albacore males and females, respectively. On an average, the proportion of fish with a fork length above $93 \mathrm{~cm}$ and below $98 \mathrm{~cm}$ represented $75 \%$ of the albacore males in this fork length range. Additionally, the proportion of fish with a fork length above $98 \mathrm{~cm}$ represented $65 \%$ of the albacore females (Fig. 3a). The least number of individuals were categorised in the fork length group of 110 to $120 \mathrm{~cm}$ and from 120 to $130 \mathrm{~cm}$. For yellowfin tuna, fork length ranged from 80 to $160 \mathrm{~cm}$ and most individuals were seen in the 110 to $130 \mathrm{~cm}$ category, representing approximately 31.6 and $70 \%$ of the total caught specimens of males and females, respectively. The least number of individuals possessed fork lengths of 140 to $160 \mathrm{~cm}$, representing $10.3 \%$ of the total specimens (Fig. 3b). Finally, for bigeye tuna, the fork length ranged from 75 to 180 $\mathrm{cm}$ and 125 to $155 \mathrm{~cm}$ category dominated the catch, representing approximately $47 \%$ of the total specimens caught. However, the individual females with fork lengths ranging from 135 to $165 \mathrm{~cm}$ were dominant, representing approximately $46.15 \%$ of the total female specimens, while the fork length range of 105 to $145 \mathrm{~cm}$ was the most dominant for the male specimens, representing approximately $66 \%$ (Fig. 3c). The length data for the three tuna species was higher than that obtained by Zhu et al. (2008) in the eastern Pacific Ocean, whose fork lengths varied from 70 to $118 \mathrm{~cm}, 93$ to $170 \mathrm{~cm}$ and 60 to $202 \mathrm{~cm}$ for albacore, yellowfin and bigeye tuna, respectively. The length range of the three tuna species in this study was in agreement with the results obtained by Hoyle et al. (2012) on albacore in the south Pacific Ocean. Our results were contrary to that of Harley et al. (2014) on bigeye tuna in the western and central Pacific Ocean.

The weight frequency distributions of the three tuna species are shown in Fig. 3. The minimum and maximum weight size ranges of the different species were: albacore tuna - 10-35 kg, yellowfin tuna - 10-80 kg and bigeye tuna - 5-110 kg. For albacore tuna, the dominant weight range was from 15 to $20 \mathrm{~kg}$, representing $55.96 \%$ of the total specimens. This weight range represented approximately 61.64 and $50.61 \%$ of the albacore males and females, respectively (Fig. 3a). The class with the least specimens ranged from 30 to $35 \mathrm{~kg}$ and represented 3.61 and $6.79 \%$ of males and females, respectively. The dominant weight range for yellowfin tuna was from 20 to $50 \mathrm{~kg}$ and represented $72.41 \%$ of the total specimens. This weight range represented $70.03 \%$ of the total female specimens and $73.68 \%$ of the total male specimens. The maximum weight of the males ranged from 50 to $60 \mathrm{~kg}$ and maximum weight of the females ranged from 60 to $80 \mathrm{~kg}$ (Fig. 3b). Finally, for bigeye tuna, the weight range from 35 to $55 \mathrm{~kg}$ was the dominant class, representing $46.88 \%$ of the total specimens. This weight range represented $33.33 \%$ of female specimens and $66.67 \%$ of male specimens. The maximum weight of the males was $108 \mathrm{~kg}$, while that of the female was $85 \mathrm{~kg}$, therefore, on average, bigeye males weighed more than females.

\section{Length-weight relationship}

Table 2 shows the regression equations of the relationship between fork length $(\mathrm{cm})$ and total weight (kg) of albacore, yellowfin and bigeye tuna caught in this study. In general, the allometric coefficients $(b)$ of the females were significantly greater than those of the males for all three species $(\mathrm{p}<0.05)$. The allometric coefficients of the three species were lower than 3 , excluding those of albacore and yellowfin tuna females, which were greater than 3 . The b-coefficients of albacore and yellowfin tuna 

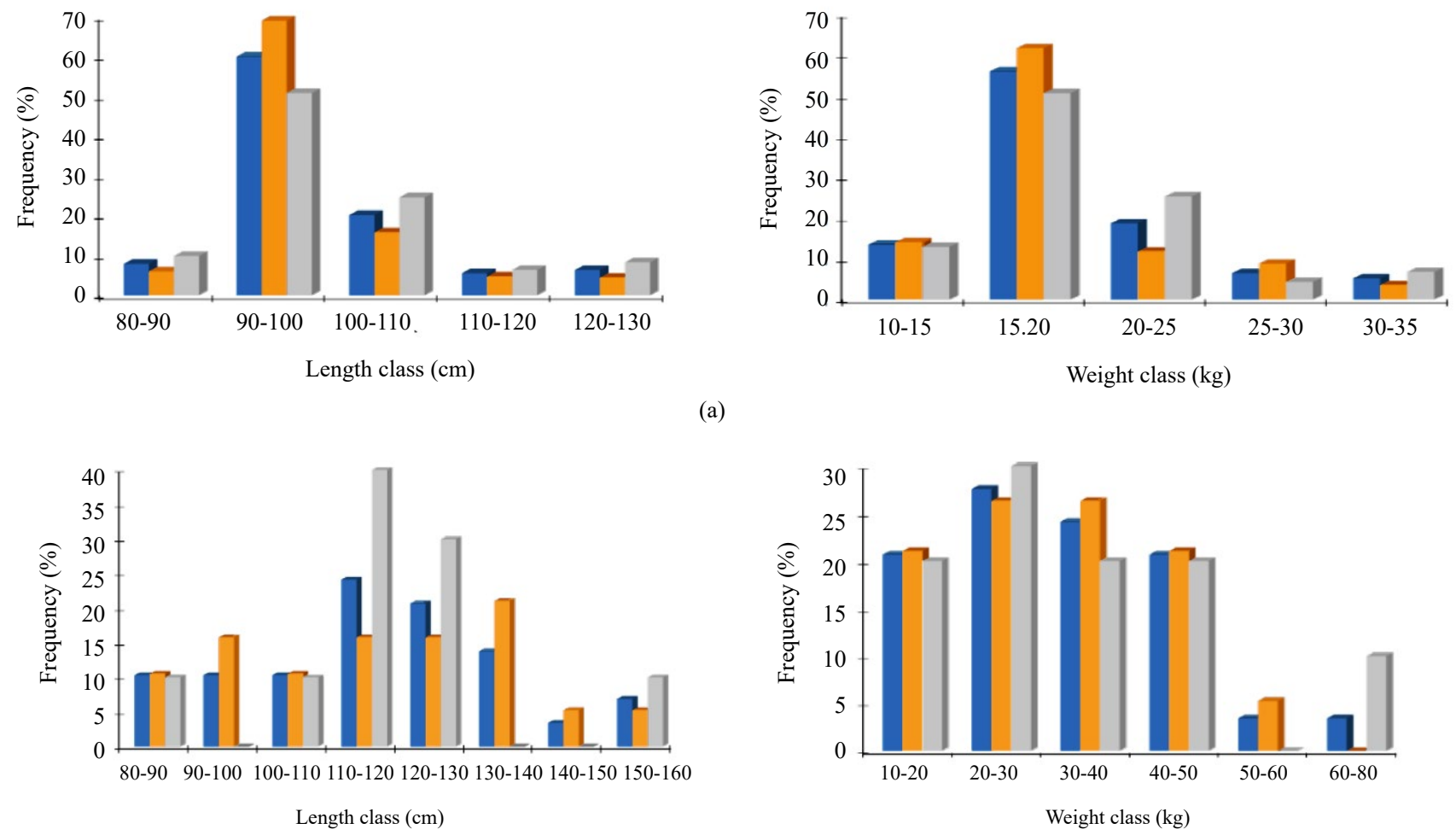

(b)
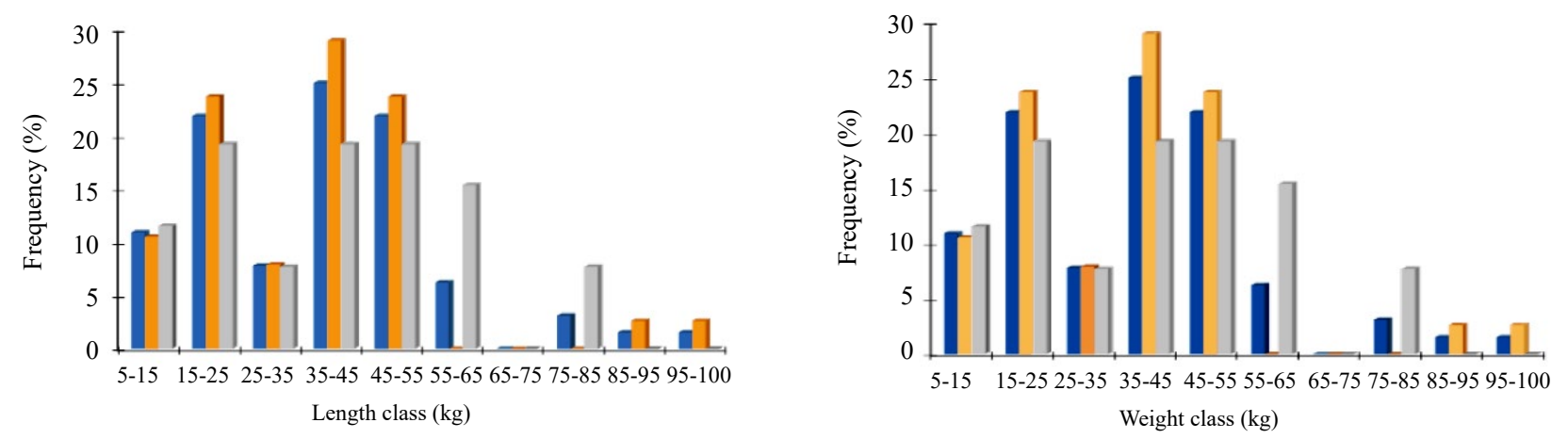

(c)

Combined sex, Male, Female

Fig. 3. Length (left) and weight (right) frequency distributions of (a) Albacore tuna, (b) Yellowfin tuna and (c) Bigeye tuna

Table 2. Length-weight relationship of albacore, yellowfin and bigeye tuna

\begin{tabular}{lllll}
\hline Species & Parameters & ${ }^{\prime}$ & $\mathrm{R}^{2}$ & $\mathrm{~b}^{\prime}$ \\
\hline Albacore tuna & Combined sex & $\mathrm{y}=7 \mathrm{E}-05 \mathrm{x}^{2.7135}$ & 0.7494 & Negative \\
& Males & $\mathrm{y}=8 \mathrm{E}-05 \mathrm{x}^{2.6845}$ & 0.7584 & Negative \\
Yellowfin tuna & Females & $\mathrm{y}=5 \mathrm{E}-06 \mathrm{x}^{3.2956}$ & 0.7784 & Positive \\
& Combined sex & $\mathrm{y}=0.0001 \mathrm{x}^{2.577}$ & 0.8329 & Negative \\
Migeye tuna & Males & $\mathrm{y}=0.0005 \mathrm{x}^{2.3263}$ & 0.8143 & Negative \\
& Females & $\mathrm{y}=7 \mathrm{E}-06 \mathrm{x}^{3.208}$ & 0.9096 & Positive \\
& Combined sex & $\mathrm{y}=0.0002 \mathrm{x}^{2.494}$ & 0.8886 & Negative \\
& Males & $\mathrm{y}=0.0002 \mathrm{x}^{2.494}$ & 0.8848 & Negative \\
\hline
\end{tabular}


males, as well as that of bigeye tuna, revealed that they all had negative allometric growth relationships, which means that the length of these species increased faster than their growth. Conversely, the albacore and yellowfin tuna females had positive allometric growth relationships, which meant that the growth of these species was faster than the increase in their lengths. In addition, the combined sex allometric coefficients of these species were less than 3 , which indicated that the length and growth of these species increased rapidly with age. There was a good fit of data to the regression $\left(\mathrm{R}^{2}\right)$ as the values of albacore, yellowfin tuna and bigeye tuna were high (Table 2). These results were similar to those obtained by Mohamed and Eldin (2012) and Zhenhua and Yu (2016). The albacore and yellowfin tuna females were characterised by positive allometry, which is similar to the results of Zhu et al. (2008) in the eastern Pacific Ocean and Hoyle et al. (2012) in the South Pacific Ocean for the yellowfin tuna and albacore tuna, respectively. The LWR of fish species is affected by certain factors, such as season, habitat, food availability, feeding rate, gonad development, sex, spawning period, health, conservation techniques and location (Froese, 2006; Zhu et al., 2008).

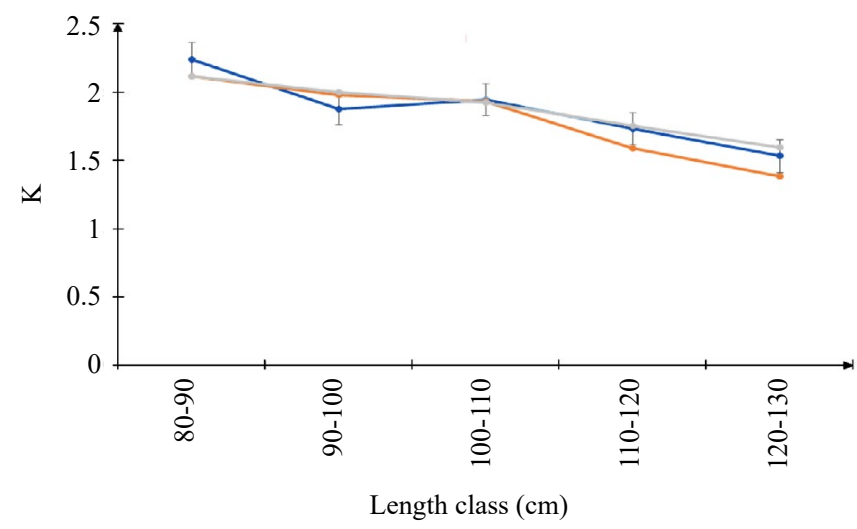

(a)
Distribution of Fulton's condition factor and relative condition factor

The average condition factor $(K)$ for the three species was $1.92 \pm 0.15,1.41 \pm 0.18$ and $1.74 \pm 0.42$ for albacore, yellowfin and bigeye tuna, respectively. In addition, the average relative condition factor $\left(K_{r e l}\right)$ was $1.01 \pm 0.08,1.34 \pm 0.31$ and $1.02 \pm 0.2$ for these three species, respectively (Table 3 ). However, the value of $K$ was greater than one for all species, which meant that our specimens were in good condition. When the sexes were combined, the $K$ values decreased as the fork length range increased (Fig. 4). The $K$ value was greater when the fork length range was $80-90$ and $85-95 \mathrm{~cm}$ for all the 3 species. For albacore tuna, the $K$ values of both the females and males were similar, with the difference less than $1 \%$ in the fork length range of $80-100 \mathrm{~cm}$. In contrast, when the fork length ranged from 110 to $130 \mathrm{~cm}$, the female $K$ values were significantly greater than those of the male $K$ values. For yellowfin tuna, the $K$ values of the males were greater than those of females for all fork length ranges except for the fork length range of $120-130 \mathrm{~cm}$, where they were equal. For bigeye tuna, the

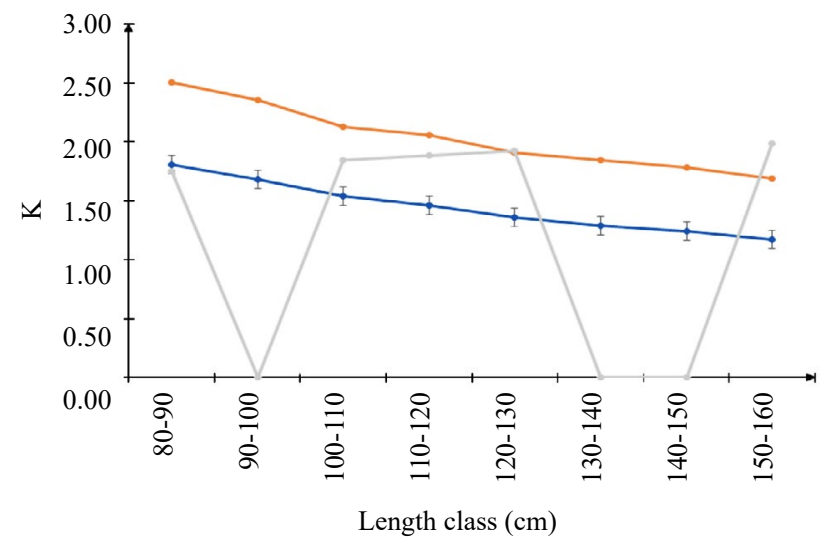

(b)

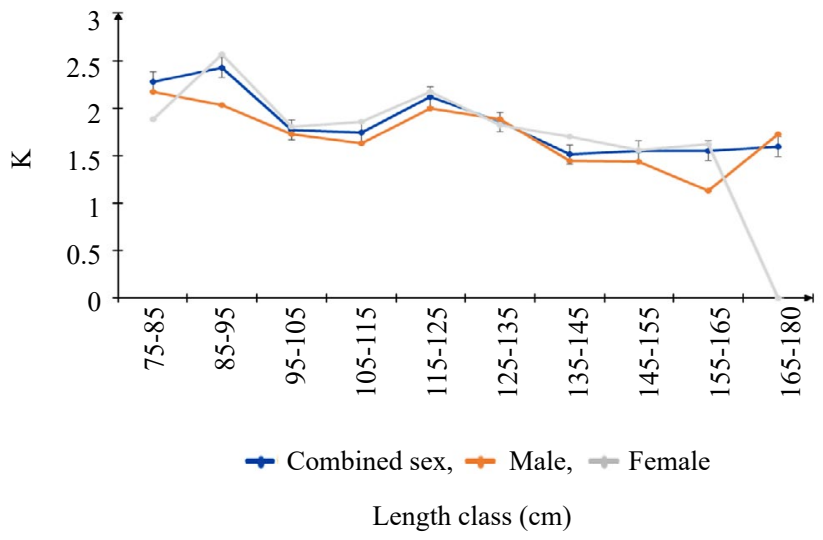

(c)

Fig. 4. Fulton's condition factor $(K)$ per fork length $(\mathrm{cm})$ class of (a) Albacore tuna, (b) Yellowfin tuna and (c) Bigeye tuna 
Table 3. Mean \pm standard deviation of Condition factor $(K)$ and Relative condition factor $\left(K_{r e l}\right)$

\begin{tabular}{llllll}
\hline Species & Parameters & Range of $K$ & Range of $K_{\text {rel }}$ & Mean \pm SD $K$ & Mean \pm SD $K_{\text {rel }}$ \\
\hline Albacore tuna & Combined sex & $1.38-2.74$ & $0.78-1.41$ & $1.92 \pm 0.15$ & $1.01 \pm 0.08$ \\
& Male & $1.38-2.74$ & $0.8-1.43$ & $1.89 \pm 0.22$ & $1.01 \pm 0.08$ \\
& Female & $1.55-2.27$ & $0.69-1.03$ & $1.92 \pm 0.15$ & $0.87 \pm 0.15$ \\
\hline Yellowfin tuna & Combined sex & $1.17-1.84$ & $0.81-1.89$ & $1.41 \pm 0.18$ & $1.34 \pm 0.01$ \\
& Male & $1.68-2.56$ & $0.71-1.32$ & $2.04 \pm 0.31$ & $0.95 \pm 0.12$ \\
& Female & $1.75-1.99$ & $0.8-1.34$ & $1.88 \pm 0.24$ & $1.02 \pm 0.06$ \\
\hline Bigeye tuna & Combined sex & $1.04-3.58$ & $0.65-1.67$ & $1.74 \pm 0.42$ & $1.02 \pm 0.06$ \\
& Male & $1.04-2.77$ & $0.64-1.39$ & $1.67 \pm 0.51$ & $0.96 \pm 0.1$ \\
& Female & $1.13-3.58$ & $0.68-1.61$ & $1.87 \pm 0.26$ & $0.99 \pm 0.09$ \\
\hline
\end{tabular}

$K$ values of females were greater than those of males for all fork lengths except for the fork length range of 75-85 and $125-135 \mathrm{~cm}$; where they were lower (Fig. 4). These results suggest that the population structure of the three species can be divided into two stages (growth stage and old stage), which aids in investigations into the sensitivity of older fish to environmental conditions (Shaofei et al., 2015). Therefore, it can be suggested that $b$ values should primarily be used to evaluate growth rates because of the high growth rate during the growing stage. Conversely, $K$ values should be used to assess the sensitivity of fish to environmental factors or health conditions. In addition, albacore tuna had higher $K$ values than the two other species, and yellowfin tuna had a greater average $K_{r e l}$ value, indicating that the albacore specimens caught had thicker bodies than yellowfin and bigeye tuna of the same length range.

This study analysed the CPUE, size frequency, LWR, relative condition factor and Fulton condition factor for catches of albacore, yellowfin and bigeye tuna of the eastern Pacific. The results showed that CPUEs of albacore, yellowfin and bigeye tuna ranged between 1.6 and $9.82 ; 1.07$ and 2.66 and 1.06 and 3.45 fish per 1000 hooks, respectively. In addition, the results of the LWR for the three fish showed a negative allometric growth pattern as indicated by the growth coefficient $(b<3)$ and positive allometric for the females of albacore and yellowfin tuna. Moreover, the three species were in good condition, as indicated by the calculated condition factor $(\mathrm{K}>1)$.

\section{Acknowledgements}

This study was financially sponsored by the National key R\&D Program of China under contract Nos. 2020YFD0901202 and 2019YFD0901502 and by the National Natural Science Foundation of China under contract No. 41806110.

\section{References}

Abad-Uribarren, A., Ortega-García, S., March, D., QuirogaBrahms, C., Galván-Magaña, F. and Ponce-Díaz, G. 2018.
Exploring spatio-temporal patterns of the Mexican longline tuna fishery in the Gulf of Mexico: A comparative analysis between yellowfin and bluefin tuna distribution. Turk. $J$. Fish. Aquat. Sci., 20(2): 113-125.

Anderson, R. O. and Neumann, R. M. 1996. Length, weight and associated structural indices. In: Murphy, B. E. and Willis, D. W. (Eds.), Fisheries techniques, $2^{\text {nd }}$ edn. American Fisheries Society, Maryland, USA, p. 447-481.

Binohlan, C., Froese, R. and Pauly, D. 1998. The length-length table. In: Froese, R.and Pauly, D. (Eds.), Fishbase 1998: Concepts, design and data sources. International Centre for Living Aquatic Resources Management, Manila, Philippines, 124 pp.

Collette, B., Acero, A., Amorim, A. F., Boustany, A., Canales Ramirez, C., Cardenas, G., Carpenter, K. E., Chang, S. K., de Oliveira Leite Jr., N., Di Natale, A., Die, D., Fox, W., Fredou, F. L., Graves, J., Guzman Mora, A., Viera Hazin, F. H., Hinton, M., Juan Jorda, M., Minte Vera, C., Miyabe, N., Montano Cruz, R., Masuti, E., Nelson, R., Oxenford, H., Restrepo, V., Salas, E., Schaefer, K., Schratwieser, J., Serra, R., Sun, C., Teixeira Lessa, R. P., Pires Ferreira Travassos, P. E., Uozumi, Y. and Yanez, E. 2011. Thunnus alalunga. In: IUCN 2012. IUCN Red List of Threatened Species. Version 2012.1. www.iucnredlist.org (Accessed 20 September 2012).

Le Cren 1951. The Length-weight relationship and seasonal cycle in gonad weight and condition in perch. J. Anim. Ecol., 20: 201-209.

Davies, N., Hoyle, S., Harley, S., Langley, A., Kleiber, P. and Hampton, J. 2011. Stock assessment of bigeye tuna in the western and central Pacific Ocean. WCPFC SC7 SA WP-02, Pohnpei, Federated States of Micronesia, p. 9-17.

Davies, N., Harley, S., Hampton, J. and McKechnie, S. 2014. Stock assessment of yellowfin tuna in the western and central Pacific Ocean. WCPFC SC10-SA-WP-04, Majuro, Republic of the Marshall Islands, p. 6-14.

De Metrio, G. and Megalofonou, P. 1988. Catch, size distribution, growth and sex ratio of swordfish (Xiphias gladius L.) in the Gulf of Taranto. FAO Fisheries Report No. 394. Food and Agriculture Organisation of the United Nations, Rome, Italy. 
Froese, R. 2006. Cube law, condition factor and weight-length relationships: History, meta-analysis and recommendations. J. Appl. Ichthyol., 22(4): 241-253.

Froese, R. and Pauly, D. 2017. FishBase (version Feb 2017). In: Roskov, Y., Abucay, L., Orrell, T., Nicolson, D., Bailly, N., Kirk, P. M., Bourgoin, T., DeWalt, R. E., Decock, W., De Wever, A., Nieukerken, E. van, Zarucchi, J. and Penev, L., (Eds.), Species 2000 and ITIS Catalogue of Life, Naturalis, Leiden, The Netherlands. www.catalogueoflife.org/col.

Goni, N., Arregui, I., Lezama, A., Arrizabalaga, H. and Moreno, G. 2009. Small scale vertical behaviour of juvenile albacore in relation to their biotic environment in the Bay of Biscay. In: Nielsen, J. L., Arrizabalaga, H., Fragoso, N., Hobday, A., Lutcavage, M. and Sibert, J. (Eds.), Tagging and tracking of marine animals with electronic devices. Reviews: Methods and technologies in fish biology and fisheries, vol. 9. Springer, Dordrecht. https://doi.org/10.1007/978-14020-9640-2_4.

Goncalves, J. M. S., Bente, L., Lino, P. G., Ribeiro, J., Canario, A. V. M. and Erzini, K.1997. Weight-length relationships for selected fish species of the small-scale demersal fisheries of the south and south-west coast of Portugal. Fish. Res., 30: 253-256.

Cosgrove, R., Arregui, I., Arrizabalaga, H., Goni, N. and Sheridan, M. 2014. New insights to behaviour of North Atlantic albacore tuna (Thunnus alalunga) observed with pop-up satellite archival tags. Fish. Res., 150: 89-99. DOI: 10.1016/j.fishres.2013.10.013.

Cosgrove, R., Arregui, I., Arrizabalaga, H., Goni, N. and Neilson, J. D. 2015. Predation of pop-up satellite archival tagged albacore (Thunnus alalunga). Fish. Res., 162: 48-52.

Grewe, P. M. and Hampton, J. 1998. An assessment of bigeye (Thunnus obesus) population structure in the Pacific Ocean based on mitochondrial DNA and DNA microsatellite analysis. SOEST 98- 05, JIMAR Contribution, 98-330.

Harley, S., Davies, N., Hampton, J. and McKechnie, S. 2014. Stock assessment of bigeye tuna in the western and central Pacific Ocean. WCPFC-SC10-2014/SA-WP-01, Rev1, 115 pp.

Hoyle, S., Hampton, J. and Davies, N. 2012. Stock assessment of albacore tuna in the South Pacific Ocean. Scientific Committee Eighth Regular Session. WCPFC-SC8-2012/ SA-WP-04.

ICCAT 2017. Report of the 2017 ICCAT Bluefin stock assessment meeting. https://www.iccat.int/Documents/SCRS/DetRep/ BFT_A SS_ENG.pdf.

Lee Sung Il, Doo Nam Kim and Simon D. Hoyle 2018. CPUE standardization of yellowfin tuna caught by Korean tuna longline fishery in the Indian Ocean, 1977-2017. IOTC2018-WPTT20-39.

Macías, D., Baez, J. C., García-Barcelona, S. and Ortiz de Urbina, J. M. 2012. Dolphinfish bycatch in Spanish
Mediterranean large pelagic longline fisheries, 2000-2010. The Sci. World J., Article ID 104389. https:// doi.org/10.1100/2012/104389.

Majkowski, J. 2007. Global fishery resources of tuna and tunalike species. FAO Fisheries Technical Paper. No. 483. Food and Agriculture Organisation of the United Nations, Rome, Italy, $54 \mathrm{pp}$.

Megalofonou, P. 1990. Size distribution, length-weight relationships, age and sex of albacore (Thunnus alalunga) in the Aegean Sea. Collect. Vol. Sci. Pap. ICCAT, 33: 154-162.

Mohamed, H. and Eldin, A. 2012. Pelagic longline fishery for albacore (Thunnus alalunga) in the Mediterranean Sea off Egypt. Turk. J. Fish. Aquat., Sci., 12: 735-741.

N'da K., Christian D. L. and Yao K. 2006a. Growth of red mullet Mullus surmuletus in the northern Bay of Biscay. Cybium, 30(1): 57-63 (In French).

N'da K., Kouassi K. D. and N'goran, Y. 2006b. Artisanal maritime fishing and marketing of white grouper Epinephelus aeneus, Geoffroy Saint Hilaire, 1817 in Coote d'Ivoir. Tropicultura, 24:107-110 (In French).

Petrakis, G. and Stergiou, K. I. 1995. Weight-length relationships for 33 fish species in Greek waters. Fish. Res., 21: 465-469.

Pepin, P. 1995. An analysis of the length-weight relationships of larval fish: Limitations of the general allometric model. Fish. Bull., 93: 419-426.

Rochman, F. Setyadji, B. and Wujdi, A. 2017. Standardising CPUE of albacore tuna (Thunnus alalunga Bonnaterre, 1788) on tuna longline fishery in eastern Indian Ocean. Indones. Fish. Res. J., 23: 29-38.

Shaofei, J., Xiaodong, Y., Heng, Z and Wei, F. 2015. Weightlength relationships and Fulton's condition factors of skipjack tuna (Katsuwonus pelamis) in the western and central Pacifc Ocean. Peer. J., 3: e758. https://doi.org/10. $7717 /$ peerj. 758 .

Sadiyah, L., Dowling, N. and Prisantoso, B. I. 2012. Developing recommendations for undertaking CPUE standardization using observer program data. Indones. Fish. Res. J., 18(1): 19-33.

Song, L., Xu, W., Cao, D. and Zhao, C.2013. Optimum soak time of tuna longline gear. J. Fish. Sci. China, 20(2): 346-350 (In Chinese with English abstract).

Song, L., Li, D. J., Liu, H. Y., Chen, P. and Li, J. 2014. Optimum soak time of pelagic longline gear targeting albacore tuna. J. Shanghai Ocean Univ., 23(2): 290-296 (In Chinese with English abstract).

Vayghan, A. H., Ming-An, L., Jinn-Shing, W., Mondal, S., Ching-Te, L. and Yi-Chen, W. 2020. Multisatellite-based feeding habitat suitability modeling of albacore tuna in the southern Atlantic Ocean. Remote Sensing, 12: 2515.

Yuta. Y. 2018. Iki Island wants to save the tuna. The diplomatic world, January 2018, p. 17 (In French). 
Zhu, G., Xu, L., Zhou, Y. and Dai, X. 2008. Length-frequency compositions and weight-length relations for bigeye tuna, yellowfin tuna and albacore (Perciformes: Scombrinae) in the Atlantic, Indian and eastern Pacific Ocean. Acta Ichthyol. Piscat., 38(2): 157-161.
Zhenhua, M. and Gang, Yu. 2016. Length-weight relationships of yellowfin tuna Thunnus albacares, skipjack tuna Katsuwonus pelamis, yaito tuna Euthynnus yaito, and blue round scad Decapterus maruadsi from Mischief Reef, South China Sea. Int. J. Innov. Stud. Aquat. Biol. Fish., 2(4): 27-30.

Date of Receipt : : 12.03.2019

Date of Acceptance : 12.04.2021 